\title{
Situation of Competence-Based Assessment Management in Teaching Mathematics: A Case Study in Junior High Schools in Ho Chi Minh City, Vietnam
}

\author{
Phan Van Quang \\ Department of Education and Training, Saigon University, Tan Binh District, 701000, Ho Chi Minh City, Vietnam.
}

\begin{abstract}
How to cite this paper: Phan Van Quang. (2021) Situation of Competence-Based Assessment Management in Teaching Mathematics: A Case Study in Junior High Schools in Ho Chi Minh City, Vietnam. Journal of Applied Mathematics and Computation, 5(3), 187-199.

DOI: 10.26855/jamc.2021.09.005
\end{abstract}

Received: August 7, 2021

Accepted: August 30, 2021

Published: September 7, 2021

*Corresponding author: Phan Van Quang, Department of Education and Training, Saigon University, Tan Binh District, 701000, Ho Chi Minh City, Vietnam.

Email: quang_196901@yahoo.com

\begin{abstract}
The research discusses the management of learning outcomes assessment in Mathematics based on junior high schools in Ho Chi Minh City. Results obtained by research methods: questionnaire survey method, in-depth interviews with 13 school managers principal, 13 leader teachers of Mathematics and 13 teachers of Mathematics in 13 districts of Ho Chi Minh City, Vietnam. The survey results show that the management of the formative assessment of high school math learning results is essential. To perform well the formative assessment of students, school managers principal must apply management functions in planning; organizing, deploying, and checking the implementation of learning outcomes assessment in Maths based on formative assessment. This survey on the current situation of management of math learning results to approach students at 26 junior high schools in Ho Chi Minh City. The actual survey of 26 school managers principal, 52 vice principals of 26 leader teachers and 216 teachers for the results of level 4 and level 3 is an important practical basis for proposing measures: strengthening management functions (planning, organization, leadership and inspection); focusing on fostering the theory for the teachers of Mathematics team on the objectives, content, methods, forms, and effective treatment of mathematical learning outcomes assessment in a formative assessment to improve the quality of education.
\end{abstract}

\section{Keywords}

Management, Competence-Based Assessment, Learning Outcomes, Junior High Schools, Mathematics

\section{Introduction}

Learning outcomes assessment is an important element in the teaching process [1, 2, 3]. School manager principals well manage learning outcomes assessment based on students' competence would help schools properly assess the competences and qualifications of students $[4,5,6,7]$.

Currently, the education system in Vietnam is changing from knowledge-based education to competence-based education, as shown in the General Education Program [8, 9, 10,11]. The innovation of the competence-based education program requires innovation in learning outcomes assessment subjects, including Mathematics at the junior high school levels, according to students' competence-based [1, 12]. Key competencies to be formed for students are: competence of 
independence and self-regulated learning, competence of communication and collaboration, competence of problem-solving and creativity $[8,9,10]$. In the general education program, Mathematics has for ages considered as an important subject, being the base for many other subjects; knowledge of Maths is also used to solve many problems in real life [13, 14].

\section{Methods and Research Results}

\subsection{Literature review}

*Assessing mathematical learning outcomes with students' competence-based approach to keep up with the development trend of world education

There are several international education assessment programs in the world: assessment program TIMSS (Trend in International Mathematics) that studies learning outcomes assessment in Mathematics and Science. The program for International Student Assessment program was initiated and directed by the Organisation for Economic Co-operation and Development (OECD). Assessment program NAEP of the United States (National Assessment of Educational Progress) is a United States national assessment program that implements students learning outcomes assessments (Quality Assurance Agency for Higher Education) [2]. The SAT (Scholastic Assessment Test/Scholastic Aptitude Test) is one of the standardized tests used for admission to American universities; SAT is administered by the U.S. College Board and developed by the ETS-Educational Testing Service. Mathematics content selected for the exam papers is limited to the scope of study in the high school curriculum in the US [15]; The SAT also assesses "competence of inferring, analyzing and problem-solving" through Mathematics, reading and writing skills. SAT results are used by many schools around the world. Overall, international and national assessment programs around the world in recent years have been based on students assessment. Students' learning outcomes are recognized and used by many countries to continue their studies globally.

*Assessing mathematical learning outcomes assessment based on students' competence meeting the requirements of education innovation in Vietnam.

In Vietnam, Circular No. 32/2018/TT-BGDDT of December 26, 2018 promulgated the new General Education Program, identifying the key abilities to be formed for students: autonomy and self-study capacity, communication and cooperation capacity, problem-solving and creativity [8] and Circular 26/2020/TT-BGDDT on August 26th, 2020 amended several provisions of assessment implemented in high schools (both of junior and senior high schools), with such innovation as assessment combined with commenting and marking. The Circular clearly states that there are four regular assessment scores; one midterm score. Assessment tests are conducted in person or online through such types as Questions and Answers (Q\&A), writing, theory, practice, learning products, learning projects (Article 7).

Thus, to keep up with the development trend of world education and international integration, the learning outcomes assessment of subjects in Vietnam today in general, of Maths in particular at junior high schools, is now in the direction of competence-based education and in the direction of development and developing the ability of the student in general.

\section{*Assessing mathematical learning outcomes based on students' competence}

According to Brookhart and McMillan [1], learning outcomes are evidence of the success of students in terms of knowledge, skills, abilities, attitudes that have been set in educational goals. Another notion is that learning outcomes are the result of a subject, a special major or a whole training course. Student learning outcomes that include the knowledge, skills and attitudes they have, these knowledge and skills are accumulated from different subjects throughout the learning process specified in the training program $[13,14]$.

According to some other authors, competence is someone's ability comprehensively to receive and apply synthesis, effectively all human potentials (knowledge, skills, attitudes, fitness, beliefs ...) to perform work or deal with a certain situation, a state in life and professional labor [16]; competence is someone's ability comprehensively to master the systems of knowledge, attitude, operation (connection) them rationally to successfully perform tasks or effectively solve problems of life [17]; competence is the synthesis of knowledge, skills and psychological attributes such as motives, excitement, willpower, affection... to carry out an activity, to solve a problem in a specific context that achieves good results [3].

Thus, learning outcomes assessment is the process of collecting, analyzing and processing information to confirm the development of learning competence through students applying knowledge, skills and attitudes to perform tasks or to solve learning situations associated with the practical context.

\section{*Assessing general competencies, key competencies in Mathematics}

According to Nguyen et al. [11], the above-mentioned training materials of the Ministry of Education and Training (p. 51), can determine the content of learning outcomes assessment in junior high schools mathematics including: 
Firstly, assessing the general, key competencies formed and developed through Mathematics:

- Competence of accounting (ability to use calculations, modeling, measuring, drawing, calculating...);

- Competence of thinking (logical thinking, critical thinking, mathematical argument...);

- Competence of problem-solving (recognize problematic situations; choose the method and settlement process; evaluate the implemented solution and generalize for the same problem);

- Competence of independence and self-regulated learning (practice, self-solving in Mathematics, solving problems of mathematical significance);

- Competence of communication and collaboration (listening, reading, writing, describing the necessary mathematical information in mathematical texts; effectively using mathematical language combined with a common language to exchange and present mathematical contents and solutions in interaction with others; confidence; respect to interring dialogue when describing, explaining mathematical contents and ideas).

- Competence of informatics (using information and communication technology as a tool to support learning and self-regulated learning).

Secondly, assessing the level of development of students' mathematical competences is described as the levels of thinking [2]. Based on this description, it is possible to determine four levels of students' mathematical competence of development to evaluate: knowing, understanding, basic application, high application (mentioned in Table 1 as below).

Table 1. Assessing the mathematical competence of students through Mathematics [8]

\begin{tabular}{ll}
\hline \multicolumn{1}{c}{ Levels } & \multicolumn{1}{c}{ Description } \\
\hline \multirow{3}{*}{ Knowing } & - Remember (recognize) the basic knowledge (concept, definition, properties, reasoning, consequences, methods, \\
& mathematical process ...). \\
& - Recognize the results, affirm the same as in textbooks, good examples. \\
& - Show basic knowledge in their language. \\
Understanding & - Solve simple mathematical situations similar to those that students have been practicing in class, as well as \\
& already in textbooks. \\
& - Create a logical connection among information. \\
Basic application & - Used to reorganize information presented like lectures of teachers or in textbooks. \\
& - Identify mathematical content in situations where problems must be solved. \\
& - Apply the synthesis of knowledge to solve relevant mathematical problems, new problems, unlike those learned \\
High Application & or presented in textbooks; know how to analyze, synthesize, generalize in a mathematical proof. \\
& - Solve problems in real life.
\end{tabular}

\section{*Learning outcomes assessment in Mathematics at junior high schools}

Mathematics is a core subject of mathematical education in the general education program, compulsory curriculum from Grade 1 to 12 in order to form and develop students mathematical competence-is "a central manifestation of compatibility with components: mathematical thinking and reasoning, mathematical modeling, mathematical problem-solving, mathematical communication; develop key knowledge and skills and create opportunities for students to experience and apply mathematics to practice" [8].

Assessing mathematical learning outcomes at junior high schools based on students' competence is the process of collecting, analyzing and processing information to confirm the development of mathematical competence of junior high school students through the application of mathematical knowledge, calculation skills, attitudes to perform tasks or solve mathematical learning situations associated with the practical context.

\subsection{Methods}

- The main method used was questionnaire. The goal of the survey is to clarify the current situation of mathematical learning outcomes assessment based on students' competence at junior high schools in Ho Chi Minh City to establish facilities and find better management measures for this activity.

- Districts which are selected for the survey, must ensure the following criteria: 1) Represent junior high school education of Ho Chi Minh City; 2) Have different quality of junior high school education of each district (1st and 2nd-grade schools; The school has been recognized by the Department of Education and Training to pass the education quality inspection and the school has not passed the education quality inspection); 3) There are urban and suburban districts; 4) The number of districts is sufficient to facilitate the survey of 13 districts. Based on the defined criteria, the topic selects the following 13 districts for the survey: District 1, District 2, District 3, District 6, District 10, District 12, Tan Binh District, Binh Tan District, Binh Chanh District, Can Now District, Nha Be District, Thu Duc District, Hoc 
Mon District in Ho Chi Minh City. Surveyors are managers (school managers principal, vice principal, Maths leader teachers), Maths teachers. The survey topic of each district 02 junior high schools includes school managers principals, vice principals in charge of Mathematics leader teachers and all Mathematics teachers of junior high schools to randomly survey the reality of math assessment activities besides students’ competence at junior high schools.

Table 2. Overview of survey participants

\begin{tabular}{lll}
\hline Survey participants & Quantity & Total \\
\hline School managers principal & 26 & 78 \\
Vice principal & 52 & 26 \\
Leader teachers of Maths & 26 & 216 \\
Teachers of Maths & 216 & 2 \\
\hline
\end{tabular}

\section{*Questionnaire survey method}

The questionnaire is carried out according to the following steps: 1) Discuss with survey subjects and experts to form the survey questionnaire; 2) Prepare the survey questionnaire for the first time; 3) Consult experts and test surveys on small samples; 4) Edit the questionnaire and compile it officially (2nd compilation); 5) Select the actual survey template using Google Drive software; 6) Organize online surveyors on Google Drive software on issues that need to be studied in the questionnaire. Questionnaires are designed for school managers principals, vice principals, leaders teachers and teachers about the content to be surveyed.

\section{*In-depth interview method}

Interviews done with school manager principals, leader teachers, teachers to define purposes, analyze and synthesize results collected in interviews and clarify more details after the answers of questionnaire. Deeply interviewing 13 districts, I chose a junior high school in which I interviewed its school manager principal, Mathematics leader teachers, and one Mathematics teacher. The identities of school manager principals, leader teachers, teachers are encrypted as follows: HT1 to HT13; TTCM1 to TTCM13; GV1 to GV13.

\section{*SPSS Software to process the database}

The scale would be labelled as follows: 1 score-Disagree/no implementation; 2 scores-Lowly agree/low implementation; 3 scores—Moderately agree/moderate implementation; 4 scores—Fairly agree/fair implementation; 5 scores-Highly agree/good implementation.

The average points were divided into such levels as: 1 score-1.8 scores: Disagree/no implementation; 1.81 scores-2.60 scores: Lowly agree/low implementation; 2.61 scores-3.40 scores: Moderately agree/moderate implementation; 3.41 scores-4.20 scores: Fairly agree/fair implementation; 4.21 scores-5 scores: Highly agree/good implementation.

Processing information obtained from the software according to the statistical method of SPSS software. Processing information obtained from SPSS statistical software, we use the analysis method through AMOS software as moment structure analysis: test scale models using CFA_Confirmatory Factor Analysis and SEM_Structural Equation Modeling. To measure model suit: Manage Mathematics learning outcomes assessment based on students' competence at junior high school in Ho Chi Minh City, chi-square (CMIN) is commonly used; Freely adjusted chi-square (CMIN/df); comparative Fit Index (CFI_); Tucker/Lewis Index (TLI_ Tucker/Lewis Index); RMSEA Index (Root Mean Square Error Approximation). CFA_Confirmatory Factor Analysis and SEM_Structural Equation Modeling is one of the research techniques applied in many fields thanks to the flexibility in modeling relationships between independent and dependent variables.

Both Hair et al. [18] and Hu and Bentler [7] agreed that the thresholds for accepting the Model Fit index in the CFA will vary based on sample size, number of factor groups, number of observed variables... and both studies also give the sample size $\mathrm{N}=250$ as the acceptable threshold divider. However, in order to avoid confusion, the authors have given a general threshold that can be applied to many cases. With Hair et al. [18], the authors divided 2 small cases; while Hu and Bentler [7] for all cases.

\subsection{Analysis of research results}

According to 2 pieces of research by Baumgartner and Homburg (1995) and of Doll, Xia, and Torkzadeh (1994), if the GFI value is below 0.9 but 0.8 or higher is still accepted.

Through real-life surveys from managers (school managers principal, vice principal, Maths leader teachers) and Mathematics teachers of junior high schools, the results of the research "Reality of managing Mathematicsl learning outcomes assessment based on students' competence at junior high schools in Ho Chi Minh City” (Figure 1) according to 
the CFA factor analysis for the data as follows: CMIN/dt $=1,702<3$ is good; CFI $=0.887>0.8$ is acceptable; TLI $=$ $0.878>0.8$ is acceptable; GFI $=0.817>0.8$ is acceptable; RMSEA $=0.047<0.06$ is good.

Through real-life surveys from managers (school managers principal, vice principal, Maths leader teachers) and Mathematics teachers of junior high schools, the results of the research "Reality of managing Mathematicslearning outcomes assessment based on students' competence at junior high school in Ho Chi Minh City” according to the SEM factor analysis for the data as follows: $\mathrm{CMIN} / \mathrm{dt}=1.834<3$ is good; $\mathrm{CFI}=0.810>0.8$ is acceptable; $\mathrm{TLI}=0.802>0.8$ is acceptable; GFI $=0.801>0.8$ is acceptable; $\mathrm{RMSEA}=0.051<0.06$ is good.

The results of the analysis and measurement achieved the above level of inspection help the researcher affirms: the linear structural model of the research problem is very reliable and effective, accurately reflect the reality of managing Maths learning outcomes assessment based on students' competence at junior high school in Ho Chi Minh City.

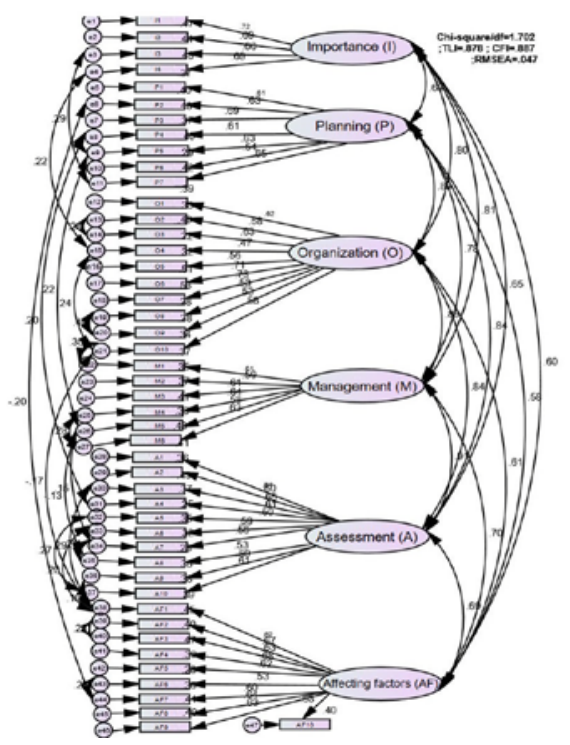

Figure 1. Confirmatory fator analysis (CFA).

*The importance of managing Mathematics learning outcome with students' competence-based approach at junior high schools

Table 3. The reality of managers and teachers about the importance of managing Mathematics learning outcome with students' competence-based approach at junior high schools

\begin{tabular}{|c|c|c|c|c|c|c|c|c|c|}
\hline \multirow[t]{2}{*}{ No. } & \multirow[t]{2}{*}{ Importance of managing activities } & \multicolumn{2}{|c|}{$\begin{array}{l}\text { School managers } \\
\text { principals, vice prin- } \\
\text { cipals, leader teach- } \\
\text { ers) }\end{array}$} & \multicolumn{3}{|c|}{ Teacher } & \multicolumn{2}{|c|}{ General } & \multirow[b]{2}{*}{ Level } \\
\hline & & Aver. & Std. & Aver. & Std. & Aver. & $\begin{array}{l}\text { Standard } \\
\text { deviation }\end{array}$ & Rank & \\
\hline 11 & $\begin{array}{l}\text { Help Maths teachers work proactively in } \\
\text { schools }\end{array}$ & 3.86 & 0.63 & 4.02 & 0.69 & 3.97 & 0.68 & 3 & Quite agree \\
\hline 22 & $\begin{array}{l}\text { Ensure the synchronized implementation } \\
\text { done by all Maths teachers within the } \\
\text { school }\end{array}$ & 3.88 & 0.75 & 4.00 & 0.69 & 3.96 & 0.71 & 4 & Quite agree \\
\hline 33 & $\begin{array}{c}\text { Ensure Maths teachers follow the guide- } \\
\text { lines }\end{array}$ & 3.87 & 0.72 & 4.13 & 0.69 & 4.04 & 0.71 & 2 & Quite agree \\
\hline 44 & $\begin{array}{c}\text { Assess the levels in Maths teachers' } \\
\text { implementation and correct mistakes in } \\
\text { time }\end{array}$ & 3.89 & 0.62 & 4.12 & 0.68 & 4.05 & 0.67 & 1 & Quite agree \\
\hline & Total & 3.88 & 0.68 & 4.07 & 0.69 & 4.00 & 0.69 & & Quite agree \\
\hline
\end{tabular}


The survey from opinions by school manager principals, vice principals, leader teachers and Maths teachers presented in Table 3 shows:

Firstly, the average scores of managers and teachers on the importance of mathematical were in the range from 3.86 to 4.13. With statistically average scores such as the table above showing managers and teachers' assessment of the importance of managing mathematical learning outcomes assessment based on students' competence at junior high schools is always at Quite agree level.

Secondly, managers rated the highest average score is Management would assess the level of implementation of Mathematics teachers and correct mistakes in time but teachers rated the average (4.12) the second highest. Teachers rated the highest average is Management would help Mathematics teachers followed the direction but managers rated the average (3.87) the lowest. Managers and teachers both assessed that Management would help Mathematics teachers work proactively, planned within the school; ensure the synchronized implementation of all Math teachers within the school is rated equally.

Thirdly, the standard deviation from the results of the importance of managing mathematical learning outcomes assessment based on students' competence at junior high schools from managers and teachers from 0.62 to 0.75 shows that the obtained figures are reliable.

In-depth interview results 13 school managers principals about the importance of managing Maths learning outcomes assessment based on students' competence at junior high schools (management would help Mathematics teachers work proactively, planned within the school;ensure the synchronized implementation of all Math teachers within the school;ensure Mathematics teachers follow the direction; assess the level of implementation of Mathematics teachers and correct mistakes in time): 13/13 school managers principals all agree with the importance and believe that without the management and unity of the school and the department, each teacher will follow different criteria and lead to the learning outcomes assessment is not synchronized, not ensure fairness among students in the same school.

The results of a deep interview with 13 leader teachers and 13 Mathematics teachers about the importance of mathematical learning outcomes assessment based on students' competence at junior high schools: 13/13 leaders and 13/13 Mathematics teachers all highly agreed with the importance of mathematical learning outcomes assessment based on students' competence at junior high schools. In addition, they claim that accessing to information technology at early age should be very dynamic. Therefore, learning outcomes assessment based on students' competence will maximize the capacity and creativity of students. As a result, the school needs to guide, adjust, restructure the system, reinvest in facilities, equipment and human resources to serve the 2018 General Education Curriculum program.

\section{*To modelize the assessment of Maths learning outcomes with students' competence-based approach}

The survey from opinions by school manager principals, vice principals, leader teachers and Maths teachers presented above has shown that:

Firstly, the average score of managers and teachers on planning the assessment launching of Maths learning outcomes with students' competence-based approach was in the range of 3.86 to 4.06. The above statistics show that managers and teachers' recognition about the assessment of Maths learning outcomes with students' competence-based approaches is always Fair implementation.

Secondly, managers rated the highest average score as Financial conditions to invest and support the activity; Sides to be implemented in learning outcomes assessment based on students' competence (objectives, content, methods, forms,...), rated the lowest average score (3.89). Teachers rated the highest average score asImplementation planning of each individual (each Maths teacher plans the implementation), but rated the lowest average score (3.89). Managers and teachers both rated People who carry out activities (3.95); Implementation planning on a school-wide scope (Maths team planning implementation in all grades) (3.91) equally.

Thirdly, the standard deviation from the results of planning the assessment activities of Maths learning outcomes with students' competence-based approach from managers and teachers between 0.46 and 0.81 shows that the obtained figures are reliable.

The results of an in-depth interview with 13 school managers principals, 13 leaders teachers, 13 teachers showed that although the use of words is different, $100 \%$ agreed on Sides to be implemented in learning outcomes assessment based on students' competence (objectives, content, methods, forms,...); People who carry out activities; Infrastructure (facilities, equipment, documents,...), financial conditions,information technology conditions to support the activity; Implementation planning on a school-wide scope (Maths team planning implementation in all grades); Implementation planning of each individual (each Maths teacher plans the implementation). However, there are still some opinions that it is necessary to pay attention to the content of the plan, clearly identify the conditions required to support Maths learning outcomes assessment to approach students' capacity (conditions of information technology, means, equipment, documents, finance ...) and the content of the plan should focus on fully identifying the sides to be implemented in Maths 
learning outcomes assessment with students' competence-based approach (objects, content, methods, forms, processing of assessment results) will be more effective in managing the assessment launching of Maths learning outcomes with students' competence-based approach.

Table 4. The reality of managers and teachers modelize the assessment launching of Maths learning outcomes with students' competence-based approach

\begin{tabular}{|c|c|c|c|c|c|c|c|c|c|}
\hline \multirow[t]{2}{*}{ No. } & \multirow[t]{2}{*}{$\begin{array}{l}\text { Modelize learning outcomes assess- } \\
\text { ment based on students' competence }\end{array}$} & \multicolumn{2}{|c|}{$\begin{array}{l}\text { School managers } \\
\text { (principals, vice } \\
\text { principals, leader } \\
\text { teachers) }\end{array}$} & \multicolumn{2}{|c|}{ Teachers } & \multicolumn{4}{|c|}{ General } \\
\hline & & Avr. & $\begin{array}{l}\text { Std. devia- } \\
\quad \text { tion }\end{array}$ & Avr. & $\begin{array}{l}\text { Std. devia- } \\
\quad \text { tion }\end{array}$ & Avr. & $\begin{array}{l}\text { Std. devia- } \\
\quad \text { tion }\end{array}$ & Rank & Level \\
\hline \multicolumn{10}{|c|}{ Contents: } \\
\hline 1 & $\begin{array}{l}\text { Sides to be implemented in learning } \\
\text { outcomes assessment based on students' } \\
\text { competence (objectives, content, me- } \\
\text { thods, forms, ...) }\end{array}$ & 4.03 & 0.57 & 3.89 & 0.64 & 3.93 & 0.62 & 5 & $\begin{array}{l}\text { Fair im- } \\
\text { plementa- } \\
\quad \text { tion }\end{array}$ \\
\hline 2 & People who carry out activities & 3.95 & 0.56 & 3.95 & 0.64 & 3.95 & 0.61 & 3 & $\begin{array}{l}\text { Fair im- } \\
\text { plementa- } \\
\quad \text { tion }\end{array}$ \\
\hline 3 & $\begin{array}{l}\text { Infrastructure (facilities, equipment, } \\
\text { documents,...) to support the activity }\end{array}$ & 3.99 & 0.76 & 4.04 & 0.73 & 4.02 & 0.74 & 1 & $\begin{array}{l}\text { Fair im- } \\
\text { plementa- } \\
\quad \text { tion }\end{array}$ \\
\hline 4 & $\begin{array}{l}\text { Financial conditions to invest and sup- } \\
\text { port the activity }\end{array}$ & 4.06 & 0.81 & 3.88 & 0.76 & 3.94 & 0.78 & 4 & $\begin{array}{l}\text { Fair im- } \\
\text { plementa- } \\
\quad \text { tion }\end{array}$ \\
\hline 5 & $\begin{array}{l}\text { Information technology conditions to } \\
\text { support the activity }\end{array}$ & 3.86 & 0.77 & 3.91 & 0.70 & 3.89 & 0.72 & 7 & $\begin{array}{l}\text { Fair im- } \\
\text { plementa- } \\
\text { tion }\end{array}$ \\
\hline & Total & 3.98 & 0.69 & 3.93 & 0.69 & 3.95 & 0.70 & & $\begin{array}{l}\text { Fair im- } \\
\text { plementa- } \\
\quad \text { tion }\end{array}$ \\
\hline \multicolumn{10}{|c|}{ Range: } \\
\hline 6 & $\begin{array}{l}\text { Implementation planning on a } \\
\text { school-wide scope (Maths team plan- } \\
\text { ning implementation in all grades) }\end{array}$ & 3.93 & 0.60 & 3.91 & 0.68 & 3.92 & 0.65 & 6 & $\begin{array}{l}\text { Fair im- } \\
\text { plementa- } \\
\quad \text { tion }\end{array}$ \\
\hline 7 & $\begin{array}{l}\text { Implementation planning of each indi- } \\
\text { vidual (each Maths teacher plans the } \\
\text { implementation) }\end{array}$ & 3.89 & 0.57 & 4.06 & 0.69 & 4.01 & 0.66 & 2 & $\begin{array}{l}\text { Fair im- } \\
\text { plementa- } \\
\text { tion }\end{array}$ \\
\hline & Total & 3.91 & 0.58 & 3.99 & 0.68 & 3.96 & 0.66 & & $\begin{array}{l}\text { Fair im- } \\
\text { plementa- } \\
\quad \text { tion }\end{array}$ \\
\hline
\end{tabular}

*Manage the assessment launching of Maths learning outcomes with students' competence-based approach

The survey from opinions by school manager principals, vice principals, leader teachers and Maths teachers presented in Table 5 shows:

Firstly, the average score of managers and teachers on Maths learning outcomes assessment with students' competence-based assessment is in the range of 3.65 to 4.12 and all reach level 4. The above statistics show that managers and teachers' recognition about the assessment of Maths learning outcomes with students' competence-based approaches is always Fair implementation.

Secondly, Managers and teachers rated the highest average score as Clearly define the management responsibilities of managers of schools; Clearly define Maths leader teachers' responsibilities for implementation and management; Clear- 
ly define Maths teachers' responsibilities are all highly rated. Managers and teachers rated Clearly assigned financial tasks to support the activity; Clearly assigned information technology tasks to support the activity; Clearly assigned tasks of supporting infrastructure for activity; Clearly assigned tasks all sides of the assessment launching of Maths learning outcomes with students' competence-based approach (objectives, content, methods, forms...) have the lowest average score and similar.

Thirdly, standard deviation from results of implementing the assessment launching of Maths learning outcomes with students' competence-based approaches at junior high schools from managers and teachers from 0.53 to 0.73 shows that the obtained figures are reliable.

Table 5. The reality of managing the assessment launching of Maths learning outcomes with students' competence-based approach

\begin{tabular}{|c|c|c|c|c|c|c|c|c|c|}
\hline \multirow[t]{2}{*}{ No. } & \multirow[t]{2}{*}{ Contents } & \multicolumn{2}{|c|}{$\begin{array}{l}\text { School managers } \\
\text { (principals, vice } \\
\text { principals, leader } \\
\text { teachers) }\end{array}$} & \multicolumn{3}{|c|}{ Teacher } & \multicolumn{3}{|c|}{ General } \\
\hline & & Avr. & $\begin{array}{l}\text { Std. devi- } \\
\text { ation }\end{array}$ & Avr. & $\begin{array}{l}\text { Std. devi- } \\
\text { ation }\end{array}$ & Avr. & $\begin{array}{l}\text { Std. devi- } \\
\text { ation }\end{array}$ & Rank & Level \\
\hline \multicolumn{10}{|c|}{ About building the apparatus } \\
\hline 1 & $\begin{array}{l}\text { Clearly define the management responsi- } \\
\text { bilities of managers of schools }\end{array}$ & 4.02 & 0.57 & 4.09 & 0.73 & 4.07 & 0.68 & 1 & $\begin{array}{l}\text { Fair im- } \\
\text { plementa- } \\
\quad \text { tion }\end{array}$ \\
\hline 2 & $\begin{array}{l}\text { Clearly define Maths leader teachers' } \\
\text { responsibilities for implementation and } \\
\text { management }\end{array}$ & 3.97 & 0.66 & 4.12 & 0.65 & 4.07 & 0.66 & 1 & $\begin{array}{l}\text { Fair im- } \\
\text { plementa- } \\
\quad \text { tion }\end{array}$ \\
\hline 3 & $\begin{array}{l}\text { Clearly define Maths teachers' responsi- } \\
\text { bilities }\end{array}$ & 3.88 & 0.60 & 4.10 & 0.67 & 4.03 & 0.66 & 3 & $\begin{array}{l}\text { Fair im- } \\
\text { plementa- } \\
\quad \text { tion }\end{array}$ \\
\hline 4 & $\begin{array}{l}\text { Clearly define support responsibilities of } \\
\text { staffs (academics, libraries, information } \\
\text { technology ...) }\end{array}$ & 3.77 & 0.69 & 3.99 & 0.71 & 3.92 & 0.71 & 7 & $\begin{array}{l}\text { Fair im- } \\
\text { plementa- } \\
\quad \text { tion }\end{array}$ \\
\hline 5 & $\begin{array}{l}\text { Clearly define the coordinated responsi- } \\
\text { bilities of form teachers }\end{array}$ & 3.89 & 0.61 & 4.02 & 0.73 & 3.98 & 0.69 & 4 & $\begin{array}{l}\text { Fair im- } \\
\text { plementa- } \\
\quad \text { tion }\end{array}$ \\
\hline 6 & $\begin{array}{l}\text { Clearly define relationship between } \\
\text { Maths teachers and students’ parents }\end{array}$ & 3.80 & 0.60 & 4.03 & 0.73 & 3.96 & 0.70 & 5 & $\begin{array}{l}\text { Fair im- } \\
\text { plementa- } \\
\quad \text { tion }\end{array}$ \\
\hline & Total & 3.89 & 0.62 & 4.06 & 0.70 & 4.00 & 0.68 & & $\begin{array}{l}\text { Fair im- } \\
\text { plementa- } \\
\quad \text { tion }\end{array}$ \\
\hline \multicolumn{10}{|c|}{ Contents assigned to parts of the apparatus: } \\
\hline 7 & $\begin{array}{l}\text { Clearly assigned tasks all sides of the } \\
\text { assessment launching of Maths learning } \\
\text { outcomes with students’ compe- } \\
\text { tence-based approach (objectives, content, } \\
\text { methods, forms,...) }\end{array}$ & 3.74 & 0.64 & 4.01 & 0.71 & 3.93 & 0.70 & 6 & $\begin{array}{l}\text { Fair im- } \\
\text { plementa- } \\
\quad \text { tion }\end{array}$ \\
\hline 8 & $\begin{array}{l}\text { Clearly assigned tasks of supporting in- } \\
\text { frastructure for activity }\end{array}$ & 3.76 & 0.53 & 3.94 & 0.67 & 3.88 & 0.63 & 8 & $\begin{array}{l}\text { Fair im- } \\
\text { plementa- } \\
\quad \text { tion }\end{array}$ \\
\hline 9 & $\begin{array}{l}\text { Clearly assigned financial tasks to support } \\
\text { the activity }\end{array}$ & 3.65 & 0.62 & 3.88 & 0.68 & 3.81 & 0.67 & 10 & $\begin{array}{l}\text { Fair im- } \\
\text { plementa- } \\
\quad \text { tion }\end{array}$ \\
\hline \multirow[t]{2}{*}{10} & $\begin{array}{l}\text { Clearly assigned information technology } \\
\text { tasks to support the activity }\end{array}$ & 3.70 & 0.61 & 3.95 & 0.67 & 3.87 & 0.66 & 9 & $\begin{array}{l}\text { Fair im- } \\
\text { plementa- } \\
\quad \text { tion }\end{array}$ \\
\hline & Total & 3.71 & 0.60 & 3.95 & 0.68 & 3.87 & 0.66 & & $\begin{array}{l}\text { Fair im- } \\
\text { plementa- } \\
\quad \text { tion }\end{array}$ \\
\hline
\end{tabular}


The results of an in-depth interview with 13 school managers principals, 13 leaders teachers, and 13 teachers showed that while the use of words was different, $100 \%$ agreed with the assessment launching of Maths learning outcomes with students' competence-based approaches. However, during the interview, it was suggested that the leadership process should increase awareness for Maths teachers to understand the urgent learning outcomes with students' competence-based approaches and focus on fostering the theory for Maths teachers on the objectives, content, methods, form, handle Maths learning outcomes with students' competence-based approaches... to ensure that Maths learning outcomes are fair, objective and accurately assess students' competence through students' learning outcomes.

\section{*Managers' implementingthe assessment of Maths learning outcomes with students' competence-based approach}

Table 6. The reality of managers and teachers in implementing the assessment launching of Maths learning outcomes with students' competence-based approach

\begin{tabular}{|c|c|c|c|c|c|c|c|c|c|}
\hline \multirow[t]{2}{*}{ No. } & \multirow[t]{2}{*}{ Contents } & \multicolumn{2}{|c|}{$\begin{array}{l}\text { Managers } \\
\text { (school managers } \\
\text { principal, vice } \\
\text { principal, leader } \\
\text { teachers) }\end{array}$} & \multicolumn{3}{|c|}{ Teachers } & \multicolumn{2}{|c|}{ General } & \multirow[b]{2}{*}{ Level } \\
\hline & & Avr. & $\begin{array}{l}\text { Std. devi- } \\
\text { ation }\end{array}$ & Avr. & $\begin{array}{l}\text { Std. devi- } \\
\text { ation }\end{array}$ & Avr. & $\begin{array}{l}\text { Std. devi- } \\
\text { ation }\end{array}$ & Rank & \\
\hline 1 & $\begin{array}{c}\text { Foster awareness for Maths teachers to } \\
\text { understand the urgent of the assessment } \\
\text { launching of Maths learning outcomes } \\
\text { with students' competence-based ap- } \\
\text { proach }\end{array}$ & 3.77 & 0.58 & 3.95 & 0.67 & 3.89 & 0.65 & 3 & $\begin{array}{l}\text { Fair im- } \\
\text { plementa- } \\
\text { tion }\end{array}$ \\
\hline 2 & $\begin{array}{l}\text { Facilitate Maths teachers to receive } \\
\text { theoretical training on Maths learning } \\
\text { outcomes with students' compe- } \\
\text { tence-based approach (objectives, con- } \\
\text { tent, methods, forms,...) }\end{array}$ & 3.85 & 0.59 & 4.02 & 0.68 & 3.96 & 0.66 & 1 & $\begin{array}{l}\text { Fair im- } \\
\text { plementa- } \\
\text { tion }\end{array}$ \\
\hline 3 & $\begin{array}{l}\text { Direct the proper implementation of } \\
\text { objectives, build content matrix, select } \\
\text { methods, forms and handling methods } \\
\text { learning outcomes with students' com- } \\
\text { petence-based approach }\end{array}$ & 3.84 & 0.59 & 4.02 & 0.70 & 3.96 & 0.67 & 1 & $\begin{array}{l}\text { Fair im- } \\
\text { plementa- } \\
\text { tion }\end{array}$ \\
\hline 4 & $\begin{array}{l}\text { Direct to ensure eligibility for support- } \\
\text { ing infrastructure for teaching activities }\end{array}$ & 3.78 & 0.54 & 3.82 & 0.70 & 3.81 & 0.65 & 6 & $\begin{array}{l}\text { Fair im- } \\
\text { plementa- } \\
\text { tion }\end{array}$ \\
\hline 5 & $\begin{array}{l}\text { Direct to ensure financial eligibility for } \\
\text { operational support }\end{array}$ & 3.73 & 0.59 & 3.96 & 0.76 & 3.89 & 0.72 & 3 & $\begin{array}{l}\text { Fair im- } \\
\text { plementa- } \\
\text { tion }\end{array}$ \\
\hline 6 & $\begin{array}{l}\text { Direct to ensure eligibility for informa- } \\
\text { tion technology to support operation }\end{array}$ & 3.81 & 0.61 & 3.83 & 0.71 & 3.82 & 0.68 & 5 & $\begin{array}{l}\text { Fair im- } \\
\text { plementa- } \\
\text { tion }\end{array}$ \\
\hline & Total & 3.79 & 0.58 & 3.93 & 0.70 & 3.89 & 0.67 & & $\begin{array}{l}\text { Fair im- } \\
\text { plementa- } \\
\text { tion }\end{array}$ \\
\hline
\end{tabular}

The survey from opinions by school manager principals, vice principals, leader teachers and Maths teachers presented in Table 6 shows:

Firstly, the average score of managers and teachers on Maths learning outcomes assessment with students' competence-based assessment is in the range of 3.73 to 4.02 and all reach level 4 . The above statistics show that managers and teachers' recognition about the assessment of Maths learning outcomes with students' competence-based approaches is 
always Fair implementation.

Secondly, managers and teachers rated the highest average score as Facilitate Maths teachers to receive theoretical training on Maths learning outcomes with students' competence-based approach (objectives, content, methods, forms,...); Direct the proper implementation of objectives, build content matrix, select methods, forms and handling methods learning outcomes with students' competence-based approach are all highly rated. Managers and teachers rated Foster awareness for Maths teachers to understand the urgent of the assessment launching of Maths learning outcomes with students' competence-based approach; Direct to ensure eligibility for supporting infrastructure for activity have the lowest average score and similar.

Thirdly, standard deviation from results of examining the assessment launching of Maths learning outcomes with students' competence-based approaches at junior high schools from managers and teachers from 0.54 to 0.71 shows that the obtained figures are reliable. The results of an in-depth interview with 13 school managers principals, 13 leaders teachers, and 13 teachers showed that while the use of words was different, 100\% agreed with the assessment launching of Maths learning outcomes with students' competence-based approaches. However, during the interview, it was suggested that the leadership process should increase awareness for Maths teachers to understand the urgent learning outcomes with students' competence-based approaches and focus on fostering the theory for Maths teachers on the objectives, content, methods, form, handle Maths learning outcomes with students' competence-based approaches... to ensure that Maths learning outcomes are fair, objective and accurately assess students' competence through students' learning outcomes.

However, during the interview, it was suggested that the process of organizing the testing function should strengthen the examination of Maths teachers' performance of maths objectives, content, methods, forms, handling the assessment of Maths teachers learning outcomes with students' competence-based, and strengthening the examination of staffs performing the task of supporting Maths with information technology conditions, vehicles, equipment, finance ... when needed.

\section{*Examine the assessment launching of Maths learning outcomes with students' competence-based approach}

The survey from opinions by school manager principals, vice principals, leader teachers and Maths teachers presented in Table 7 shows:

Firstly, the average score of managers and teachers on Maths learning outcomes assessment with students' competence-based assessment is in the range of 3.85 to 4.32 . The above statistics show that managers and teachers' recognition about the assessment of Maths learning outcomes with students' competence-based approaches is always Fair implementation.

Secondly, managers rated the highest average score as Preliminary review and summary (semester, academic year) on assessment activities Maths learning outcomes assessment with students' competence-based approaches; Check the performance of coordinated tasks of form teachers; Inspection of the implementation of the regulations of the Mathematics team and each Maths teacher in Maths learning outcomes assessment with students' competence-based approaches all reach level 4: Fair implementation. But teachers rated the highest average score as Check the implementation of the in learning outcomes assessment based on students' competence (4.32) reach level 5: Good implementation; check the assurance of financial conditions and monitor adjustment after the inspection is Fair implementation. Managers rated the lowest average score (3.83) as Check the implementation of the in learning outcomes assessment based on students' competence (objectives, content, methods, forms,...); Check the assurance of financial conditions (3.89). But teachers rated the lowest average score (3.79) as Check the performance of coordinated tasks of form teachers; Check the performance of support tasks of staffs (academics, libraries, information technology ...) reach level Fair implementation. Elaboration of regulations Maths learning outcomes assessment with students' competence-based approaches; Elaboration of regulations Maths learning outcomes assessment with students' competence-based approaches have an approximately equal average score and reach level Fair implementation.

Thirdly, standard deviation from results of examining the assessment launching of Maths learning outcomes with students' competence-based approaches at junior high schools from managers and teachers from 0.55 to 0.78 shows that the obtained figures are reliable.

The results of an in-depth interview with 13 school managers principals, 13 leaders teachers, and 13 teachers showed that while the use of words was different, $100 \%$ agreed with the assessment launching of Maths learning outcomes with students' competence-based approaches. However, during the interview, it was suggested that the process of organizing the testing function should strengthen the examination of Maths teachers' performance of maths objectives, content, methods, forms, handling the assessment of Maths teachers learning outcomes with students' competence-based, and strengthening the examination of staffs performing the task of supporting Maths with information technology conditions, vehicles, equipment, finance ... when needed. 
Table 7. The reality of managers and teachers in examing the assessment launching of Maths learning outcomes with students' competence-based approach

\begin{tabular}{|c|c|c|c|c|c|c|c|c|c|}
\hline \multirow[t]{2}{*}{ S No. } & \multirow[t]{2}{*}{ Contents } & \multicolumn{2}{|c|}{$\begin{array}{c}\text { Managers } \\
\text { (school managers } \\
\text { principal, vice } \\
\text { principal, leader } \\
\text { teachers) }\end{array}$} & \multicolumn{2}{|c|}{ Teachers } & \multicolumn{4}{|c|}{ General } \\
\hline & & Avr. & $\begin{array}{l}\text { Std. devia- } \\
\quad \text { tion }\end{array}$ & Avr. & $\begin{array}{l}\text { Std. devia- } \\
\quad \text { tion }\end{array}$ & Avr. & $\begin{array}{l}\text { Std. devia- } \\
\quad \text { tion }\end{array}$ & Rank & Level \\
\hline \multicolumn{10}{|c|}{ About contents will be examined: } \\
\hline 11 & $\begin{array}{l}\text { Check the implementation of the in } \\
\text { learning outcomes assessment based } \\
\text { on students' competence (objectives, } \\
\text { content, methods, forms,...) }\end{array}$ & 3.83 & 0.58 & 4.00 & 0.73 & 3.94 & 0.69 & 5 & $\begin{array}{l}\text { Fair im- } \\
\text { plementa- } \\
\quad \text { tion }\end{array}$ \\
\hline 22 & $\begin{array}{l}\text { Check the assurance of infrastruc- } \\
\text { ture conditions }\end{array}$ & 3.97 & 0.63 & 3.89 & 0.63 & 3.92 & 0.63 & 7 & $\begin{array}{l}\text { Fair im- } \\
\text { plementa- } \\
\quad \text { tion }\end{array}$ \\
\hline 33 & $\begin{array}{c}\text { Check the assurance of financial } \\
\text { conditions }\end{array}$ & 3.89 & 0.65 & 4.05 & 0.77 & 4.00 & 0.73 & 4 & $\begin{array}{l}\text { Fair im- } \\
\text { plementa- } \\
\quad \text { tion }\end{array}$ \\
\hline 44 & $\begin{array}{l}\text { Check the assurance of information } \\
\text { technology conditions }\end{array}$ & 3.97 & 0.70 & 3.85 & 0.70 & 3.89 & 0.70 & 8 & $\begin{array}{l}\text { Fair im- } \\
\text { plementa- } \\
\quad \text { tion }\end{array}$ \\
\hline & Total & 3.92 & 0.64 & 3.95 & 0.71 & 3.94 & 0.69 & & \\
\hline \multicolumn{10}{|c|}{ About inspection process: } \\
\hline 55 & $\begin{array}{l}\text { Elaboration of regulations Maths } \\
\text { learning outcomes assessment with } \\
\text { students' competence-based ap- } \\
\text { proaches }\end{array}$ & 4.00 & 0.62 & 3.90 & 0.61 & 3.93 & 0.62 & 6 & $\begin{array}{l}\text { Fair im- } \\
\text { plementa- } \\
\quad \text { tion }\end{array}$ \\
\hline 66 & $\begin{array}{l}\text { Inspection of the implementation of } \\
\text { the regulations of the Mathematics } \\
\text { team and each Maths teacher in } \\
\text { Maths learning outcomes assess- } \\
\text { ment with students’ compe- } \\
\text { tence-based approaches }\end{array}$ & 4.05 & 0.67 & 4.32 & 0.76 & 4.23 & 0.74 & 1 & $\begin{array}{c}\text { Good } \\
\text { imple- } \\
\text { mentation }\end{array}$ \\
\hline 77 & $\begin{array}{l}\text { Check the performance of support } \\
\text { tasks of staffs (academics, libraries, } \\
\text { information technology ...) }\end{array}$ & 3.98 & 0.67 & 3.79 & 0.55 & 3.85 & 0.60 & 10 & $\begin{array}{l}\text { Fair im- } \\
\text { plementa- } \\
\quad \text { tion }\end{array}$ \\
\hline 88 & $\begin{array}{l}\text { Check the performance of coordi- } \\
\text { nated tasks of form teachers }\end{array}$ & 4.08 & 0.63 & 3.79 & 0.60 & 3.88 & 0.63 & 9 & $\begin{array}{l}\text { Fair im- } \\
\text { plementa- } \\
\quad \text { tion }\end{array}$ \\
\hline 99 & Monitor adjustments after inspection & 4.05 & 0.61 & 4.08 & 0.72 & 4.07 & 0.69 & 2 & $\begin{array}{l}\text { Fair im- } \\
\text { plementa- } \\
\quad \text { tion }\end{array}$ \\
\hline \multirow[t]{2}{*}{110} & $\begin{array}{l}\text { Preliminary review and summary } \\
\text { (semester, academic year) on as- } \\
\text { sessment activities Maths learning } \\
\text { outcomes assessment with students' } \\
\text { competence-based approaches }\end{array}$ & 4.12 & 0.66 & 4.00 & 0.78 & 4.04 & 0.74 & 3 & $\begin{array}{l}\text { Fair im- } \\
\text { plementa- } \\
\quad \text { tion }\end{array}$ \\
\hline & Total & 4.04 & 0.65 & 3.98 & 0.67 & 4.00 & 0.67 & & $\begin{array}{l}\text { Fair im- } \\
\text { plementa- } \\
\quad \text { tion }\end{array}$ \\
\hline
\end{tabular}




\section{Conclusion}

Managing the assessment of students' learning outcomes in Maths with competence-based approach include its importance, its planning, its implementation. The fact-checking survey made by the school manager principals, vice principals, leader teachers and teachers shows that the full implementation of management functions (modeling, deploying, examining the assessment), fully shows the objectives, content, forms, methods and processing shown in assessment of students' learning outcomes with the competence-based approach. Although the processing in Ho Chi Minh City has been carried out methodically, according to the documents directed by the Ministry of Education and Training, the Department of Education and Training but the quality, as well as its efficiency is still low. There is not evenness among schools in one district, among districts in Ho Chi Minh City; unscientific and not in line with reality along with the development of technology in the world. The reality also shows the role of students' learning outcomes assessment within the competence-based approach junior high schools is one of the important tasks in every school, contributing to ensuring the education quality. Therefore, in order for learning outcomes assessments at schools being effectively organized, school manager principals are expected to make sure of their functions as a manager. The article provides such important information that it could probably help school manager principals in the junior high schools to revise, learning from experiences, finding better management measures for students' learning outcomes in Maths with the competence-based approach in particular and in general at junior high schools.

\section{References}

[1] Brookhart, S. M. and McMillan, J. H. (2020). “Classroom Assessment and Educational Measurement”, 2020. DOI: https://doi.org/10.4324/9780429507533.

[2] Tran, K. and Tran, D. C. (2012). "Doi moi cong tac danh gia ve kiem tra danh gia cua hoc sinh truong trung hoc co so" (Innovation in assessment and testing of junior high school students' learning outcomes), Vietnam Education Publishing House, 2012.

[3] Vu, T. R. and Pham, X. Q. "Kiem tra danh gia ket qua hoc tap mon Vat li cua hoc sinh o truong pho thong theo dinh huong phat trien nang luc" (Assessment).

[4] Dolin, J. and Evans, R. (2021). "Tranforming assessment—-through an interplay between practice, research and policy”, 2021.ISBN 978-3-319-63248-3.

[5] Frey, N. and Fisher, D. (2011). "The formative assessment action plan - Practical steps to more successful teaching and learning”, 2011. ISBN-13: 978-1-4166-1169-1.

[6] Frith, D. S. and Macintosh, H. G. (1988). “A teacher’s Guide to Assessment”, Stanley Thomes Ltd, 1988.

[7] $\mathrm{Hu}, \mathrm{L}$. and Bentler P. M. (1999). "Cutoff criteria for fit indexes in covariance structure analysis: Conventional criteria versus new altematives”, Structural Equation Modeling indicators considered for evaluatiy Model Fit, 1999. DOI https://doi.org/10.1080/10705519909540118.

[8] Ministry of Education and Training, “General Education Curriculum”, 2018.

[9] Nguyen, C. K. (2019). "Doi moi danh gia hoc sinh pho thong theo cach tiep can nang luc" (Innovation in competence-based assessment of students' learning outcomes), Hanoi National University of Education, 2019.

[10] Nguyen, M. T. (2019). "Hoi dap ve Chuong trinh giao duc pho thong” (FAQs of General education curriculum), University of Education Publishing House, 2019.

[11] Nguyen, S. H. "Nhung uu viet cua giao duc dua tren nang luc" (Pros of competence-based education), https://vnexpress.net/nhung-uu-viet-cua-giao-duc-dua-tren-nang-luc-3699548.html (Accessed March 22nd 2019).

[12] Arikan, S., Erkin, E., and Pesen, M. (2020). "Development and Validation of a STEM competencies assessment framework", International Journal of Science and Mathematics Education, 2020. DOI: 10.1007/s10763-020-10132-3.

[13] Nortvedt, G. A. and Buchholtz, N. (2018). "Assessment in Mathematics education: responding to issues regarding methodology, policy, and equity”, pp. 555-570, 2018. DOI: 10.1007/s11858-018-0963-z.

[14] Tran, T. T. (2020). "Phat trien nang luc danh gia ket qua hoc tap cua hoc sinh cho sinh vien nganh su pham Toan" (Developing the competence of students' learning outcomes for undergraduates majored in Education of Maths), dissertation of Doctorate, Thai Nguyen University, University of Education, 2020.

[15] Do, A. K. "Ky thi SAT: Moi dieu co ban ban can biet" (Everything you should know about SAT), Hotcourse 
Vietnam member of IDP, https://www.hotcourses.vn/study-in-usa/choosung-a-university/all-about-sat-test/ (Accessed on September 20th 2020)

[16] Tran, K. D. (2013). "Nghien cuu nhu cau va xay dung mo hinh dao tao theo nang luc trong linh vuc giao duc" (Research on needs and promoting competence-based training model in education), Vietnam National University, 2013.

[17] Nguyen, C. K. and Dao, T. O. (2015). “Giao trinh kiem tra - danh gia trong giao duc” (Textbook of educational assessment and testing), University of Education Publishing House, 2015.

[18] Hair, J. F., Babin, B. J., Anderson, R. E., and Black, W. C. (2010). “Multivariate Data Analysis”, 7th edition, 2010. 